\title{
Survey of vector-borne and nematode parasites involved in the etiology of anemic syndrome in sheep from Southern Brazil
}

\author{
Pesquisa de hemoparasitos transmitidos por vetores e nematódeos \\ envolvidos na etiologia de síndrome anêmica em ovinos no Sul do Brasil \\ Anna Claudia Baumel Mongruel' ${ }^{1}$; ; Viviane Campos Spanhol' ${ }^{1}$; Jessica Damiana Marinho Valente ${ }^{1} \mathbb{C}^{2}$;

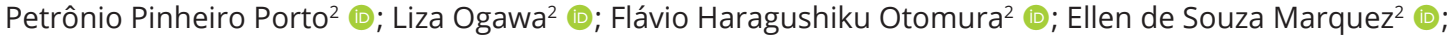

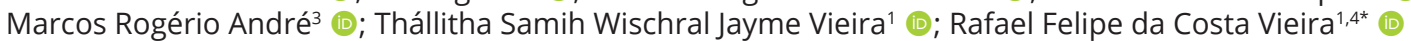 \\ ${ }^{1}$ Vector-Borne Diseases Laboratory, Departamento de Medicina Veterinária, Universidade Federal do Paraná - UFPR, Curitiba, PR, Brasil \\ ${ }^{2}$ Departamento de Ciências Biológicas, Universidade Estadual do Norte do Paraná - UENP, Bandeirantes, PR, Brasil \\ ${ }^{3}$ Laboratório de Imunoparasitologia, Departamento de Patologia, Teriogenologia e Saúde Única, Faculdade de Ciências Agrárias e \\ Veterinárias - FCAV, Universidade Estadual Paulista - Unesp, Jaboticabal, SP, Brasil \\ ${ }^{4}$ Global One Health initiative - GOHi, The Ohio State University, Columbus, OH, USA
}

How to cite: Mongruel ACB, Spanhol VC, Valente JDM, Porto PP, Ogawa L, Otomura FH, et al. Survey of vector-borne and nematode parasites involved in the etiology of anemic syndrome in sheep from Southern Brazil. Braz J Vet Parasitol 2020; 29(3): e007320. https://doi.org/10.1590/S1984-29612020062

\begin{abstract}
Although anemia has been historically linked to Haemonchus contortus infection, other infectious agents, such as hemotropic mycoplasmas and tick-borne disease pathogens, may also lead to anemic crisis in sheep. This study has aimed to investigate infections related to anemia in a sheep herd from Bandeirantes City, Paraná State, southern Brazil. Seven out of forty-two (16.6\%; 95\% CI: 8.32-30.6\%) sheep were positive for hemoplasmas by a PCR targeting the $16 \mathrm{~S}$ rRNA gene and all tested negative for A. marginale/A. ovis and Babesia/Theileria spp. by PCR based on msp4 and 18S rRNA genes, respectively. Two (4.7\%; 95\% Cl: 1.32-15.79\%) animals were infested with Rhipicephalus microplus ticks. Fecal egg counting was performed in 38 sheep and 24 (63.15\%; 95\% Cl: 47.2-76.6\%) presented $>500$ eggs per gram. Phylogenetic analysis of partial sequences of the detected hemotropic Mycoplasma sp. 16S and 23S rRNA genes confirmed that the animals were infected with Mycoplasma ovis. Polymorphism analysis of partial 16S rRNA sequences showed three different genotypes of $M$. ovis infecting sheep assessed in the present study. Mycoplasma ovis and gastrointestinal nematodes occurs in sheep from the northern region of Paraná State.
\end{abstract}

Keywords: Small ruminants, hemoplasmas, Mycoplasma ovis, Anaplasma marginale, piroplasmids, gastrointestinal nematodes.

\begin{abstract}
Resumo
Embora a principal causa de anemia seja historicamente relacionada à infecção por Haemonchus contortus, outros agentes infecciosos, como micoplasmas hemotrópicos e patógenos transmitidos por carrapatos, também podem causar quadros anêmicos em ovinos. O presente estudo objetivou investigar infecções relacionadas à anemia em um rebanho de ovinos, na cidade de Bandeirantes, Estado do Paraná, sul do Brasil. Sete (16,6\%; 95\% Cl: 8,32-30,6\%) de 42 ovinos foram positivos para hemoplasmas pela PCR do gene 16S rRNA, enquanto todos foram negativos para A. marginale/A. ovis e Babesia/Theileria spp. por ensaios da PCR baseados nos genes msp4 e 18S rRNA, respectivamente. Dois (4,7\%; 95\% Cl: 1,32-15,79\%) animais estavam infestados por carrapatos Rhipicephalus microplus. Dos 38 animais nos quais foi realizada a contagem de ovos por grama de fezes (OPG), 24 (63,15\%; 95\% Cl: 47,2-76,6\%) apresentaram valores >500 para OPG. A análise filogenética das sequências parciais dos genes 16S rRNA e 23S rRNA de hemoplasmas confirmou a infecção por Mycoplasma ovis. A análise de polimorfismos de um fragmento do gene 16S rRNA mostrou a ocorrência de três genótipos diferentes de $M$. ovis nos animais. Mycoplasma ovis e nematódeos gastrointestinais ocorrem em ovinos da região nordeste do Estado do Paraná.
\end{abstract}

Palavras-chave: Pequenos ruminantes, hemoplasmas, Mycoplasma ovis, Anaplasma marginale, piroplasmas, nematódeos gastrointestinais. 


\section{Introduction}

Brazilian sheep herd has been estimated to comprise more than 18 million animals. The southern region of Brazil is home to $30 \%$ of the herd, which are mainly reared for meat production (IBGE, 2016). Anemia is considered a concerning condition for animal health leading to production losses. Gastrointestinal (GI) parasites and vector-borne pathogens (VBP) have been considered an important cause of anemia in sheep worldwide.

The GI parasite Haemonchus contortus, which parasitizes the sheep's abomasum and causes acute hemorrhagic anemia, may lead to sudden death and important losses in sheep industry (Lane et al., 2015; Taylor et al., 2007). Although anemia is commonly linked to $H$. contortus infection in sheep, it is noteworthy that other infectious agents, such as hemotropic mycoplasmas (hemoplasmas) and VBP may also lead to anemic crisis (Yeruham et al., 1998; Neimark et al., 2004; Hornok et al., 2009; Alessandra \& Santo, 2012). Nevertheless, VBP have not been historically included in the differential diagnosis of anemia by veterinary practitioners in Brazil.

Hemoplasmas are small and pleomorphic bacteria of red blood cells that infect many different species of vertebrate hosts (Messick, 2004). Even though two hemoplasma species have been initially reported, namely Mycoplasma ovis (formerly Eperythrozoon ovis) and 'Candidatus Mycoplasma haemovis' (Hornok et al., 2012). The complete genome sequence of $M$. ovis (strain Michigan) revealed two copies of the 16S rDNA genes, which corresponded to the previously reported sequences of $M$. ovis and ' $C a$. M. haemovis' (Deshuillers et al., 2014). In sheep, M. ovis infection may cause weight loss, hyperthermia, mucosal pallor, and hemolytic anemia (Neimark et al., 2004; Aktas \& Ozubek, 2017; Martínez-Hernández et al., 2019). In Brazil, M. ovis has been detected in deer (Grazziotin et al., 2011a, b; André et al., 2020), goats (Machado et al., 2017), and sheep (Souza et al., 2019).

Anaplasma marginale, the causative agent of bovine anaplasmosis, has been detected in goats from the northeastern region of Brazil (Da Silva et al., 2018) and sheep from Iran (Yousefi et al., 2017). However, the epidemiological and clinical effects of $A$. marginale infection in small ruminants remain to be fully established. On the other hand, Anaplasma ovis has been reported infecting sheep and goats from different countries, such as Italy (De La Fuente et al., 2005), Hungary (Hornok et al., 2007), Iran (Jalali et al., 2013), China (Zhang et al., 2016; Yang et al., 2018), and Turkey (Aktas \& Ozubek, 2018). Although A. ovis infection often causes mild pathogenicity in sheep (Hornok et al., 2007; Renneker et al., 2013), its occurrence is highly involved in concurrent infections with different hemoparasite species in sheep (Jalali et al., 2013; Yang et al., 2015; Sevinc et al., 2018; Ringo et al., 2018), which may contribute to aggravating animal clinical conditions (Aktas \& Ozubek, 2018). To date A. ovis has never been reported infecting small ruminants in Brazil. Despite the high host specificity of Rhipicephalus microplus to cattle (Dantas-Torres et al., 2009; Ma et al., 2016), this tick species may be found parasitizing small ruminants (Brito et al., 2005; Da Silva et al., 2018).

A wide range of Piroplasmorida species, mainly from the genera Theileria and Babesia, may infect sheep. Although piroplasmid infections in small ruminants may be considered negligible when compared to cattle infections, the number of studies regarding these tick-borne agents has raised with the increasing economic interest in these animals (Schnittger et al., 2003; Ozubek \& Aktas, 2017). These infections may cause fever, anorexia, mucosal pallor, hemoglobinuria, and anemia in sheep (Yeruham et al., 1998; Hassan et al., 2015). Rhipicephalus, Hyalomma, and Haemaphysalis ticks have been incriminated as putative vectors for these agents (Morzaria, 1998; Tian et al., 2004; Uilenberg, 2006). In Brazil, studies on piroplasmid infection in sheep have not been reported so far.

Co-infection with $M$. ovis and other pathogens, such as GI nematodes and tick-borne pathogens, may lead to hemolytic anemia and reflect on production decay and mortality (Hornok et al., 2009; Abdullah et al., 2013). Although ovine production has a notable importance, only one study on $M$. ovis has been reported in sheep from Brazil (Souza et al., 2019), whereas the occurrence of $A$. marginale and piroplasmids in sheep from this country remains unknown. Accordingly, the present study aimed to investigate the role of VBP and GI nematodes in the occurrence of anemia in a sheep herd from southern Brazil.

\section{Material and Methods}

\section{Ethical approval}

This study was approved by the Ethics Committee for Animal Experimentation and Animal Welfare of Universidade Federal do Paraná (protocol 030/2019) and conducted according to the ethical principles of animal experimentation, adopted by the Brazilian College of Animal Experimentation. 
Study

A total of 42 female sheep from Bandeirantes municipality (2306' $\left.28^{\prime \prime S} 50^{\circ} 21^{\prime} 36^{\prime} \mathrm{W}\right)$, Paraná State, southern Brazil, were evaluated for the presence of hemoplasmas, tick-borne pathogens (Anaplasma spp., Babesia spp., and Theileria spp.), and GI parasite infection. The animals were co-grazed with cattle in a paddock, where tick infestation is common during the entire year.

\section{Sampling}

Blood samples (up to $5 \mathrm{~mL}$ ) were collected from the sheep by venipuncture of the jugular vein in commercial tubes containing EDTA (BD Vacutainer ${ }^{\circledast}$, Franklin Lakes, NJ, USA). Fecal samples were obtained directly by rectal collection, identified, and stored in isothermal recipients until analysis.

Ticks found on animals were directly removed using a commercial hook (O'TOM Tick Twister ${ }^{\circledR}$, Lavancia, France), and kept in labeled absolute ethanol-containing tubes until identification according to morphological taxonomic keys (Barros-Battesti et al., 2006).

\section{Evaluation of packed cell volume}

The packed cell volume (PCV) was measured by centrifugation (10,000 rpm for five minutes). A PCV value of $<0.27 \mathrm{~L} / \mathrm{L}$ was used as an indicator of anemia (Weiss et al., 2010). Thereafter, aliquots of blood were stored at $-20{ }^{\circ} \mathrm{C}$ until molecular testing.

\section{DNA extraction}

Isolation of genomic DNA from sheep blood samples was performed using a commercial kit (llustraTM Blood GenomicPrep Mini Spin Kit, GE Healthcare, Little Chalfont, UK). Nuclease-free water was used as negative control to monitor cross-contamination.

\section{Polymerase Chain Reactions (PCR)}

A conventional PCR for the mammalian endogenous gene glyceraldehyde-3-phosphate dehydrogenase (gapdh) was performed for all samples to monitor the DNA extraction, as previously described (Birkenheuer et al., 2003). Thereafter, DNA samples were tested using a conventional pan-hemoplasma PCR assay targeting a fragment (900 bp) of the 16S rRNA gene of hemoplasmas (Hoelzle et al., 2011; Machado et al., 2017). This assay has been validated for the diagnostic of hemoplasmas and is able to detect 4.32 DNA copies/ $\mu \mathrm{L}$ (Machado et al., 2017).

The primer set targeting a fragment of the $23 \mathrm{~S}$ rRNA gene of hemoplasmas was designed using Primer3 software (Koressaar \& Remm, 2007; Untergasser et al., 2012) and commercially synthesized (Integrated DNA Technologies, Coralville, IA, USA). Briefly, the 23S rRNA gene sequences of hemotropic Mycoplasma spp. (NR_076982, NR_103993, AB740012, HE613254, NR_121969, NR_103970, NR_076983) available in the GenBank ${ }^{\circledR}$ database were retrieved and aligned using Bioedit v. 7.0.5.3 software (Hall, 1999). Potential target sites for forward primers were manually identified; suitable reverse primers and PCR products were selected using Primer3 software (Koressaar \& Remm, 2007; Untergasser et al., 2012). Based on the desired product size (800-1,000 bp), melting temperature, minimal pair complementarity, and minimal pair 3'-complementarity (to avoid primer-dimer or hairpin formation), one reverse primer was selected. To verify the proprieties of each primer, PCR suitability tests were performed using SMS software (Sequence Manipulation Suite, Edmonton, Alberta, Canada). The specificity of the prospective primers was checked in silico by BLASTn analysis (Altschul et al., 1999) in order to determine the identity with the sequences deposited in the GenBank ${ }^{\otimes}$ database. The primer set used to amplify an 800-bp fragment was 23S_HAEMO_F (5'-TGA GGG AAA GAG CCC AGA C-3') and 23S_HAEMO_R (5'-GGA CAG AAT TTA CCT GAC AAG G-3').

For the standardization of 23S rRNA PCR protocol, a PCR mixture containing 1X PCR buffer, $1.5 \mathrm{mM}$ of $\mathrm{MgCl}_{2}, 0.2 \mathrm{mM}$ of each dNTP, $0.4 \mathrm{mM}$ of each primer, $2.5 \mathrm{U}$ of Taq DNA Polymerase (Taq ${ }^{\circledR}$ PCR Master Mix Kit, QIAGEN, Hilden, Germany), $5 \mu \mathrm{L}$ of DNA template, made to a final volume of $25 \mu \mathrm{L}$ with water. The cycling conditions consisted of denaturation at $94{ }^{\circ} \mathrm{C}$ for $3 \mathrm{~min}$, followed by 35 cycles of denaturation at $94{ }^{\circ} \mathrm{C}$ for $30 \mathrm{~s}$, annealing over a gradient of temperature $\left(53,54,55,56\right.$, and $57{ }^{\circ} \mathrm{C}$ ) for $30 \mathrm{~s}$, extension at $72{ }^{\circ} \mathrm{C}$ for $60 \mathrm{~s}$, final extension at $72^{\circ} \mathrm{C}$ for $10 \mathrm{~min}$, and cooling at $4{ }^{\circ} \mathrm{C}$. Additionally, a second gradient of annealing temperature was tested $\left(52,52.5,53,53.5,54\right.$, and $\left.54.5^{\circ} \mathrm{C}\right)$, and the annealing temperature was determined 
to be $54{ }^{\circ} \mathrm{C}$. The efficacy of a gradient of primer concentration was also determined ( 0.4 and $0.2 \mathrm{mM}$ of each primer), and the concentration of $0.2 \mathrm{mM}$ of each primer showed a band with higher intensity. Mycoplasma haemofelis DNA obtained from a naturally infected cat (Marcondes et al., 2018) and nuclease-free water were used as positive and negative controls, respectively. The amplified PCR products were subjected to gel electrophoresis on $1.5 \%$ agarose gels for $1 \mathrm{~h}$ at $100 \mathrm{~V}$, and the gels were stained with SYBR $(0.1 \mu \mathrm{L} / \mathrm{mL}$ gel) $\left(\right.$ SYBR $^{\text {TM }}$ Safe, Thermo Scientific, Waltham, MA, USA), and visualized under a $312 \mathrm{~nm}$ UV light transilluminator (LTB HE, Loccus do Brasil, São Paulo, BR).

Additionally, sheep DNA blood samples were also tested by PCR assays targeting a fragment (870 bp) of msp4 gene of A. ovis/A. marginale (De La Fuente et al., 2007), and a fragment (551 bp) of the $18 \mathrm{~S}$ rRNA gene of Theileria spp./Babesia spp. (Almeida et al., 2012). Anaplasma marginale and Babesia vogeli DNA obtained from naturally infected cattle (de Souza Ramos et al., 2019) and dogs (Mongruel et al., 2018), respectively, were used as positive controls. Nuclease-free water was used as negative control.

\section{Sequencing}

Amplicons obtained from three samples that were positive for hemoplasmas were extracted and purified from the gel by enzymatic purification (ExoSAP-ITTM PCR Product Cleanup Reagent, Thermo Scientific, Waltham, USA), evaluated by spectrophotometry for concentration and purity (NanoDrop ${ }^{\mathrm{TM}}$ One Spectrophotometer, Thermo Scientific, Waltham, USA), and sequenced from both directions by the Sanger's method (3500 Genetic Analyzer, Applied Biosystems, Foster City, CA, USA). Thereafter, the sequences were subjected to BLASTn analysis (Altschul et al., 1999) for determining the identity with sequences previously deposited in the GenBank $^{\circledR}$ database. The nucleotide sequences of the 16S rRNA and 23S rRNA genes of $M$. ovis amplified in this study were submitted to the GenBank ${ }^{\circledast}$ database (GenBank ${ }^{\circledR}$ accession nos. MN173878-MN173880 and MN169108-MN169110, respectively).

\section{Phylogenetic analysis}

The partial sequences of $16 \mathrm{~S}$ and $23 \mathrm{~S}$ rRNA genes were subjected to multiple alignment with sequences selected from GenBank ${ }^{\circledast}$ using MAFFT available on the GUIDANCE 2 server (Sela et al., 2015) for each gene. The best-fit model of nucleotide substitution was determined using jModeltest v.2.1.10 (Darriba et al., 2012) and was set as $\mathrm{HKY}+\mathrm{G}$ based on the Akaike Information Criterion (AIC). Each Bayesian reconstruction was performed in Beast 1.8.0 (Li \& Drummond, 2012) with three independent runs of 30 million MCMC steps sampled at every 5,000 trees, $10 \%$ of the burn-in. The phylogenetic tree was visualized with FigTree software version 1.4.3 (Rambaut, 2014) and the final layout was done with Inkscape version 0.92.3 (Albert et al., 2018). The $16 \mathrm{~S}$ rRNA tree was rooted with Mycoplasma bovis and Bacillus subtilis whereas the 23S rRNA tree was rooted with Mycoplasma pneumoniae and Bacillus subtilis.

\section{Genotype analysis of hemoplasmas}

Mycoplasma ovis 16S rRNA sequences were analyzed to determine the number and diversity of found genotypes, using the DnaSP software version 5.10.1 (Librado \& Rozas, 2009).

\section{Parasitological analysis}

Fecal samples were analyzed by the eggs per gram (EPG) technique (Gordon \& Whitlock, 1939). Animals presenting an EPG > 500 were considered positive (Ueno \& Gonçalves, 1998).

\section{Statistical analysis}

A non-parametric Mann-Whitney test or a parametric unpaired Student's t test was used to compare the mean PCV values between M. ovis-positive and negative sheep and EPG-positive and negative sheep. The Chi-square or Fisher's exact test was used to determine associations between anemia and presence of ticks with positivity to M. ovis and between anemia and EPG positive results. Odds ratio (OR), 95\% confidence interval and $p$ values were calculated for each variable. Results considered significantly different when $p<0.05$. Data were compiled and analyzed in Epi Info'm software (version 7.1.5, CDC). 


\section{Results}

The mean PCV for sheep was 0.30 L/L. Nine out of 42 (21.42\%; $95 \% \mathrm{Cl}: 11.71-35.94 \%)$ animals were anemic. A total of 38 sheep were evaluated by EPG. Four out of 42 animals did not present feces at the time of sampling and were not evaluated. Twenty-four (63.15\%; 95\% Cl: 47.2-76.6\%) animals presented EPG values $>500$ and were considered positive for Strongylida-type eggs. A total of 24 adult tick specimens were collected from 2 out of 42 (4.76\%; 95\% Cl: 1.32-1.57\%) animals and all were identified as $R$. microplus.

For all samples, the mammalian-endogenous gapdh gene was consistently amplified. Seven out of forty-two (16.6\%; 95\% Cl: 8.32-30.6\%) animals were PCR-positive for hemoplasmas. Only one animal that was PCR-positive for hemoplasma was anemic ( $P C V=0.17 \mathrm{~L} / \mathrm{L}$ ) and presented an EPG value of 4,550. Five sheep were concomitantly positive for Mycoplasma spp. and Strogylida-type eggs. The results are summarized in Table 1. All samples tested negative for Anaplasma spp. and Babesia/Theileria spp. by PCR assays.

Table 1. Obtained results regarding PCV values, amplification of the Mycoplasma spp. 16S rRNA fragment by PCR, EPG values and, tick presence/identification in sheep from the present study.

\begin{tabular}{|c|c|c|c|c|c|c|c|c|c|c|c|}
\hline \multirow{2}{*}{\multicolumn{2}{|c|}{ Variable }} & \multicolumn{5}{|c|}{ Mycoplasma - PCR } & \multicolumn{5}{|c|}{ EPG } \\
\hline & & \multirow{2}{*}{$\frac{+/ \mathbf{n}}{1 / 9}$} & \multirow{2}{*}{$\frac{(\%)}{11.11}$} & \multirow{2}{*}{$\frac{\text { OR }}{0.5625}$} & \multirow{2}{*}{$\frac{95 \% \mathrm{Cl}}{0.06-5.39}$} & \multirow{2}{*}{$\begin{array}{c}\boldsymbol{P} \text {-value } \\
0.5278\end{array}$} & \multirow{2}{*}{$\frac{+/ n}{6 / 9}$} & \multirow{2}{*}{$\frac{(\%)}{66.67}$} & \multirow{2}{*}{$\frac{\text { OR }}{1.8824}$} & \multirow{2}{*}{$\begin{array}{c}95 \% \mathrm{Cl} \\
0.40-8.82\end{array}$} & \multirow{2}{*}{$\begin{array}{c}\boldsymbol{P} \text {-value } \\
0.4765\end{array}$} \\
\hline Anemia & Yes & & & & & & & & & & \\
\hline & No & $6 / 33$ & 18.18 & & & & $17 / 33$ & 51.52 & & & \\
\hline \multirow{2}{*}{$\begin{array}{l}\text { Presence of } \\
\text { Ticks }\end{array}$} & Yes & $1 / 2$ & 50.00 & 5.6667 & $0.31-103.45$ & 0.3089 & & & & & \\
\hline & No & $6 / 40$ & 15.00 & & & & & & & & \\
\hline \multirow[t]{2}{*}{ EPG } & Yes & $3 / 23$ & 13.04 & 0.5265 & $0.10-2.90$ & 0.3884 & & & & & \\
\hline & No & $4 / 19$ & 21.05 & & & & & & & & \\
\hline
\end{tabular}

$+=$ Number of positive animals; $\mathrm{n}=$ number of samples; $95 \% \mathrm{Cl}=95 \%$ Confidence Interval; OR = odds ratio. The mean PCV for all hemotropic Mycoplasma-PCR positive sheep ( $0.28 \mathrm{~L} / \mathrm{L})$ and EPG positive sheep $(0.28 \mathrm{~L} / \mathrm{L})$ was not significantly different when compared to $M y c o p / a s m a-P C R$ negative sheep (0.29 L/L) and EPG negative sheep (0.29 L/L) (P> 0.05). EPG-negative: 32.30, 31.60, 27.40, 29.10, 23.90, 28.10, 27.00, 21.50, 32.40, $32.70,28.60,31.60,30.50,34.40,34.30,29.20,38.10,15.00,34.00$

Three hemoplasma $16 \mathrm{~S}$ rRNA sequences obtained in the present study showed $>99 \%$ identity with multiple M. ovis sequences previously deposited in GenBank ${ }^{\circledR}$ (accession IDs no. KU98374, KU983745, KU512718, JF931135, KF313922, MH615809). Besides, the obtained three hemoplasma 23S rRNA sequences showed 100\% identity with M. ovis previosly deposited in GenBank ${ }^{\circledR}$ (accession no. NR_121969). The phylogenetic analysis of 16S (Figure 1) and $23 \mathrm{~S}$ rRNA (Figure 2) genes confirmed that the sampled sheep were infected with M. ovis. The genotype analysis based on the 16S rRNA gene showed the presence of three different haplotypes, one for each analyzed sequence. Values obtained on haplotype diversity analysis are $\mathrm{h}$ (number of haplotypes): 3; $\mathrm{Hd}$ (haplotype diversity): 1,0000; and $\pi$ (nucleotide diversity per site): 0,00000.

No significant association was found between anemia $(p=0.5278)$, presence of ticks $(p=0.3089)$, EPG values $>500(p=0.38848)$ and positivity to $M$. ovis. Also, no significant association was found between anemia $(p=0.4765)$ and $E P G$ values $>500$ (Table 2$)$.

\section{Discussion}

Worldwide, anemia in small ruminants has been generally linked to GI nematode infections (Kaplan et al., 2004; Adogwa et al., 2005; Di Loria et al., 2009). Likewise, veterinary practitioners in Brazil have not historically included VBP in the differential diagnosis of anemia. Anemia may be more severe when the animal is coinfected with nematodes and $M$. ovis. Although a previous study reported an outbreak of $M$. ovis infection that caused death of sheep from Argentina (Aguirre et al., 2009), the anemic status related to M. ovis infection is generally less severe if sheep are kept under good nutritional conditions and do not have a severe worm burden (Messick, 2004). In the present study, one out of nine anemic sheep $(P C V=0.17 \mathrm{~L} / \mathrm{L})$ was infected with $M$. ovis and also presented a high EPG value $(4,550)$. The Strongylida suborder includes important parasites for ovine livestock, such as $H$. contortus, that may 


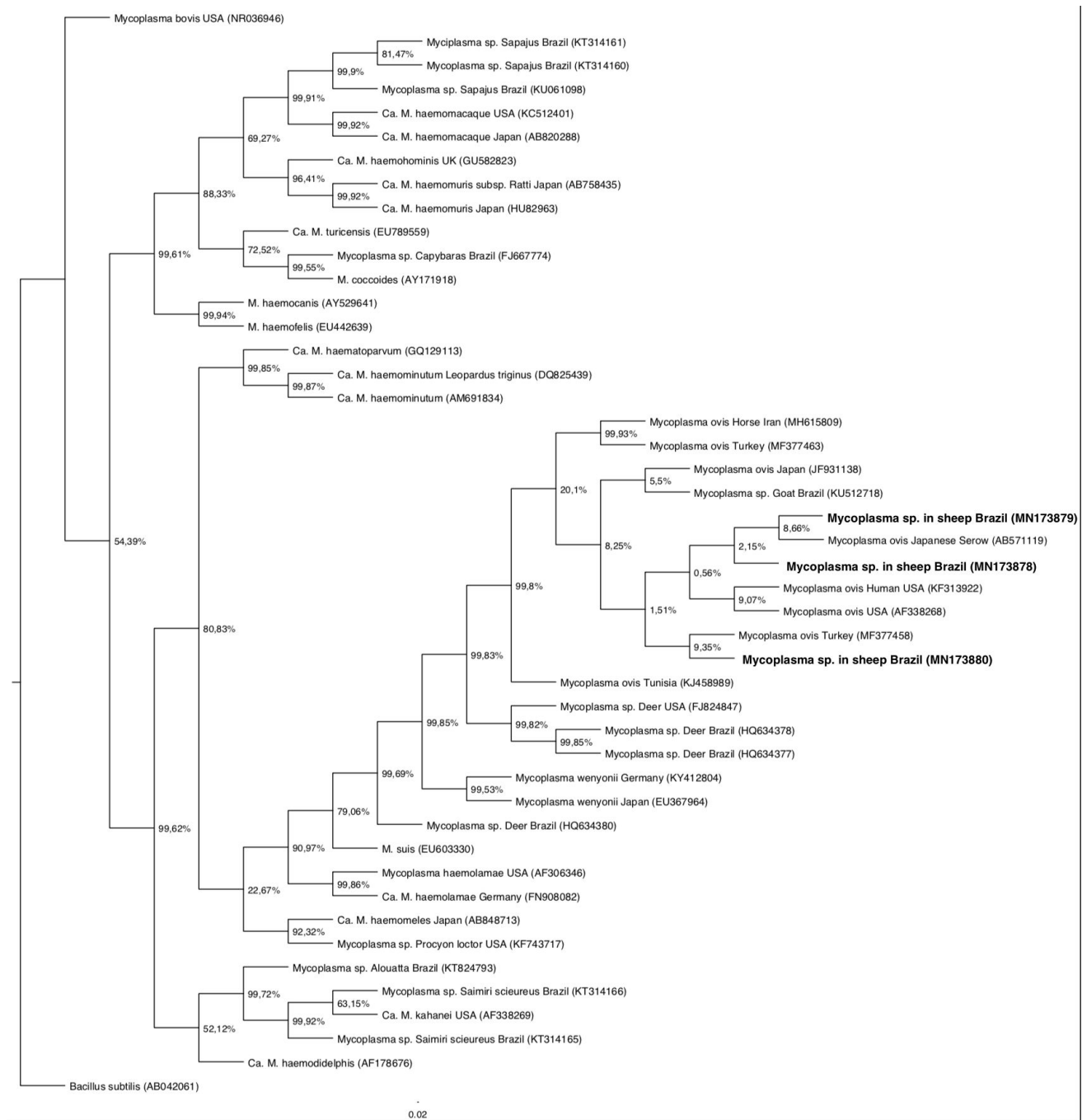

Figure 1. Phylogenetic tree based on partial sequences of the $16 \mathrm{~S}$ rDNA gene, showing the relationship between the Mycoplasma sp. detected in sheep from this study and other hemoplasmas by Bayesian Inference. Bacilus subitilis (AB042061) was used as an outgroup. GenBank accession number is after the species name and origin of each bacterium. Analyses were carried out applying the $\mathrm{F} 81+\mathrm{I}+\mathrm{G}$ model and 1000 bootstrap replicates for all analyses.

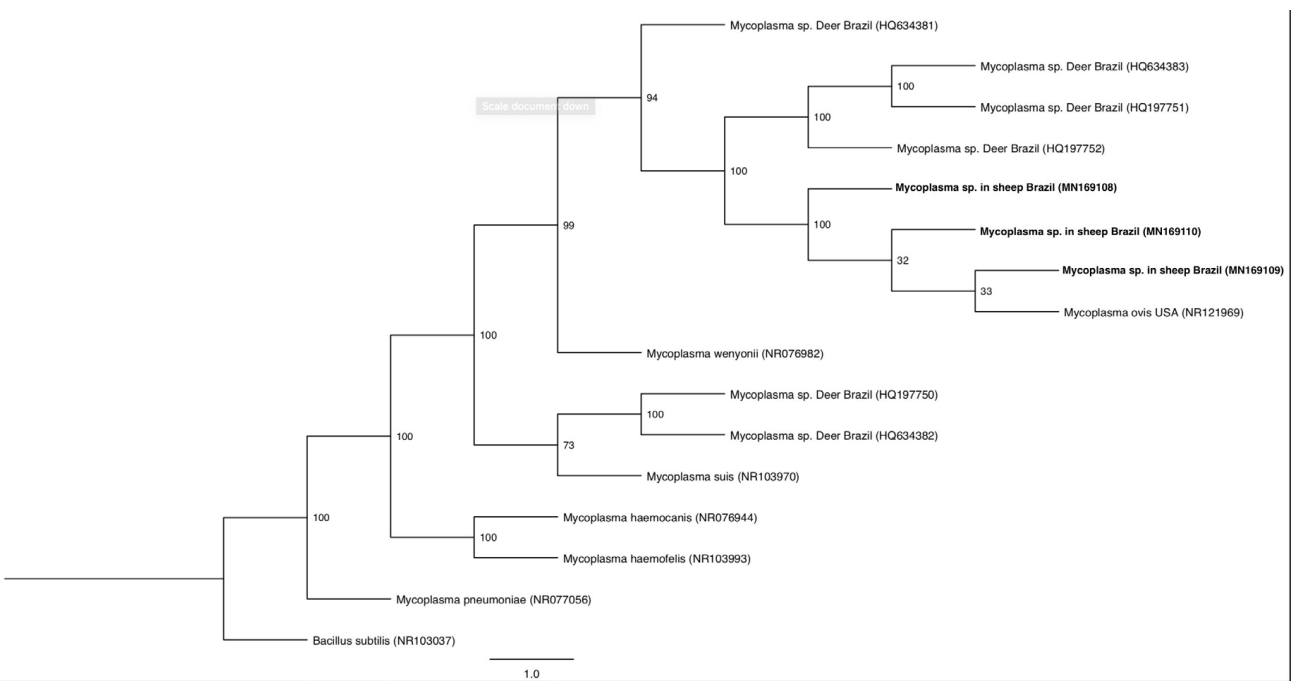

Figure 2. Phylogenetic tree based on partial sequences of the $23 \mathrm{~S}$ rDNA showing the relationship between the Mycoplasma sp. detected in sheep from this study and other hemoplasmas by Bayesian Inference. Bacilus subitilis (AB042061) was used as an outgroup. GenBank accession number is after the species name and origin of each bacterium. Analyses were carried out applying the $\mathrm{F} 81+\mathrm{I}+\mathrm{G}$ model and 1000 bootstrap replicates for all analyses. 
Survey of vector-borne and nematode parasites in sheep from Southern Brazil

Table 2. Prevalence of M. ovis-positive and EPG-positive (>500) sheep within each variable studied, Paraná State, southern Brazil.

\begin{tabular}{|c|c|c|c|c|}
\hline Animal identification & $\begin{array}{l}\text { PCV } \\
\text { (L/L) }\end{array}$ & Mycoplasma PCR result & Parasitological analysis (EPG) & Presence of $R$. microplus ticks \\
\hline 1 & 0.29 & + & 7,950 & \\
\hline 2 & 0.32 & + & 250 & \\
\hline 3 & 0.23 & & Negative & \\
\hline 4 & 0.28 & & 450 & \\
\hline 5 & 0.27 & & 300 & \\
\hline 6 & 0.31 & + & 450 & \\
\hline 7 & 0.27 & + & Negative & 1 male and 10 females \\
\hline 8 & 0.21 & & Not collected & \\
\hline 9 & 0.32 & & Negative & \\
\hline 10 & 0.29 & & 1,750 & \\
\hline 11 & 0.32 & & Negative & \\
\hline 12 & 0.28 & & Negative & \\
\hline 13 & 0.21 & & 5,200 & \\
\hline 14 & 0.31 & & 900 & \\
\hline 15 & 0.19 & & 2,750 & \\
\hline 16 & 0.30 & & 50 & \\
\hline 17 & 0.34 & & 1,550 & \\
\hline 18 & 0.23 & & 3,400 & \\
\hline 19 & 0.34 & & 350 & \\
\hline 20 & 0.34 & & Not collected & \\
\hline 21 & 0.33 & + & 2,000 & \\
\hline 22 & 0.26 & & 3,500 & \\
\hline 23 & 0.29 & + & Not collected & \\
\hline 24 & 0.29 & & 400 & \\
\hline 25 & 0.38 & & 150 & \\
\hline 26 & 0.20 & & 800 & 1 male and 12 females \\
\hline 27 & 0.29 & & 1,450 & \\
\hline 28 & 0.31 & & 950 & \\
\hline 29 & 0.29 & & 2,150 & \\
\hline 30 & 0.31 & & 500 & \\
\hline 31 & 0.28 & & 3,400 & \\
\hline 32 & 0.35 & & 1,200 & \\
\hline 33 & 0.33 & & 2,150 & \\
\hline 34 & 0.15 & & Not collected & \\
\hline 35 & 0.34 & & Not collected & \\
\hline 36 & 0.33 & & 500 & \\
\hline 37 & 0.32 & & 2,950 & \\
\hline 38 & 0.27 & & 4,500 & \\
\hline 39 & 0.28 & & 7,000 & \\
\hline 40 & 0.17 & + & 4,550 & \\
\hline 41 & 0.29 & & 1,050 & \\
\hline 42 & 0.36 & & 1,700 & \\
\hline
\end{tabular}

EPG = Eggs Per Gram of feces; bold values, PCV values $<0.27$ L/L. 
lead animals to severe anemic conditions (Amarante, 2014), and thus, may explain the anemic status of the animals studied herein. The remainder eight anemic sheep also presented high values of EPG, ranging from 800 to 5,200.

The present study aimed to investigate infections related to anemia in a sheep herd from southern Brazil. Herein, $M$. ovis was detected in $16.6 \%$ of the sampled sheep. Previous studies on the detection of M. ovis in Brazil have reported prevalence rates of 39.30\% in goats (Machado et al., 2017), 40-87\% in deer (Grazziotin et al., 2011a, b; André et al., 2020) and 78.8\% in sheep (Souza et al., 2019). Although Souza et al. (2019) detected a higher percentage of positivity to $M$. ovis in sheep from the state of Rio Grande do Sul, divergences on climate conditions, herd management, and employed PCR assays used may explain differences on hemoplasma prevalence rates between studies. Additionally, association between anemia $(p=0.5278)$ or the presence of ticks $(p=0.3089)$ and $M$. ovis infection were not found, similar to that reported in previous studies involving sheep (Rjeibi et al., 2015; Souza et al., 2019) and goats (Machado et al., 2017). Moreover, associations between anemia and EPG values $>500$ were not found as well.

It is important to state that there are some limitations on the present study. A convenience sampling was performed in order to investigate infections related to anemia in the studied sheep herd. Although all animals from the herd have been sampled, a low number of samples were provided. Furthermore, conventional PCR assays may present a low sensitivity when compared to quantitative PCR and may leads to false negative results (Willi et al., 2007). Thus, the prevalence found herein may be higher.

Phylogenetic analysis of the $16 \mathrm{~S}$ and $23 \mathrm{~S}$ rRNA gene sequences from sheep that were positive for hemoplasmas confirms that animals were infected with M. ovis. In the present study, while two M. ovis $16 \mathrm{~S}$ rRNA gene sequences (MN173878 and MN173879) clustered together with M. ovis isolated from Japanese serows (Capricornis crispus) from Japan (AB571119), the MN173880 sequence clustered together with a M. ovis sequence from Turkish sheep (MF377458). The analysis for polymorphisms showed that three different haplotypes of $M$. ovis were infecting sheep in the studied herd. The presence of polymorphisms may cause incongruities in the post-test probability values, which may explain the low values obtained. Additionally, phylogenetic analysis of the $M$. ovis $16 \mathrm{~S}$ rRNA gene showed marked differences from sequences isolated from the same herd. Genotype diversity of $M$. ovis has been previously reported in flocks from China (Wang et al., 2017) and Mexico (Martínez-Hernández et al., 2019) and, more recently, among deer from Brazil (André et al., 2020). Interestingly, the human-associated M. ovis genotypes were more related to genotypes detected in sheep and goats when compared to those found in deer (André et al., 2020). Therefore, future studies aiming to investigate the occurrence of $M$. ovis infection in sheep herd workers are needed.

Even though the 16S rRNA gene has been widely used for phylogenetic analysis, intra-genomic heterogeneities are considered a limiting factor (Rajendhran \& Gunasekaran, 2011). In 2014, the genome sequencing of M. ovis strain Michigan was reported, showing the presence of two copies of the $16 \mathrm{~S}$ rRNA gene (Deshuillers et al., 2014). The primers used in the present study cannot specifically target one or another copy from the M. ovis-16S rRNA, which may represent unreliable data in sequence analysis.

Regarding the partial 23S rRNA amplification from hemoplasmas, the three sequences amplified in the present study showed $100 \%$ identity with $M$. ovis 23 S rDNA gene sequence isolated from the USA and deposited in GenBank ${ }^{\otimes}$ (accession no. NR121969). The sequences amplified in the present study clustered together with those of $M$. ovis isolates from sheep from the USA and also formed a large clade with $M$. ovis genotypes detected in deer from Brazil. There are few studies in which the phylogenetic relationship of $M$. ovis has been determined on the basis of $23 \mathrm{~S}$ rRNA gene assembly. The analysis presented in this study shows similar results with that performed by Grazziotin et al. (2011b), wherein the $M$. ovis deer-related sequences clustered separately from those of the $M$. haemofelis group. Low post-test probability values were also obtained in the $23 \mathrm{~S}$ rRNA phylogeny of our sequences, which may be related to the genotype diversity among them.

In the present study, all sheep tested negative for A. ovis/A. marginale and Babesia/Theileria spp. by PCR. Although there are no reports on the detection of $A$. ovis and $A$. marginale or piroplasm infection in sheep from Brazil, $A$. marginale has been detected in goats co-grazed with cattle in the northeastern region of the country (Da Silva et al., 2018). Anaplasma marginale is a common tick-borne pathogen that primarily infects cattle from tropical and subtropical areas (Kocan et al., 2010), being transmitted by R. microplus ticks in Brazil (Kessler, 2001). 


\section{Conclusion}

Mycoplasma ovis and GI nematodes occurs in sheep from the northern region of Paraná State and were not related with anemia in the present study. Different genotypes of $M$. ovis occur in sheep from the northern region of Paraná State.

\section{References}

Abdullah FFJ, Adamu L, Jamal MHAB, Osman AY, Haron AW, Awang DN, et al. Parasitic Gastro-Enteritis (PGE) concurrent with Eperythrozoonosis in a Goat: Case Report. IOSR J Agric Vet Sci 2013; 4(1): 63-66. http://dx.doi.org/10.9790/2380-0416366.

Adogwa A, Mutani A, Ramnanan A, Ezeokoli C. The effect of gastrointestinal parasitism on blood copper and hemoglobin levels in sheep. Can Vet J 2005; 46(11): 1017-1021. PMid:16363328.

Aguirre DH, Thompson C, Neumann RD, Salatin AO, Gaido AB, Echaide ST. Brote de micoplasmosis clínica por Mycoplasma ovis en ovinos de Salta, Argentina. Diagnóstico clínico, microbiológico y molecular. Rev Argent Microbiol 2009; 41(4): 212-214. PMid:20085183.

Aktas M, Ozubek S. A molecular survey of small ruminant hemotropic mycoplasmas in Turkey, including first laboratory confirmed clinical cases caused by Mycoplasma ovis. Vet Microbiol 2017; 208: 217-222. http://dx.doi.org/10.1016/j.vetmic.2017.08.011. PMid:28888641.

Aktas M, Ozubek S. Anaplasma ovis genetic diversity detected by major surface protein $1 \mathrm{a}$ and its prevalence in small ruminants. Vet Microbiol 2018; 217: 13-17. http://dx.doi.org/10.1016/j.vetmic.2018.02.026. PMid:29615245.

Albert M, Andler J, Bah T, Barbry-Blot P, Barraud JF, Barton C, et al. Inkscape v. 0.48. 2018 [cited 2019 Oct 10]. Available from: http://inkscape.org

Alessandra T, Santo C. Tick-borne diseases in sheep and goats: clinical and diagnostic aspects. Small Rumin Res 2012; 106S: S6S11. http://dx.doi.org/10.1016/j.smallrumres.2012.04.026.

Almeida AP, Marcili A, Leite RC, Nieri-Bastos FA, Domingues LN, Martins JR, et al. Coxiella symbiont in the tick Ornithodoros rostratus (Acari: argasidae). Ticks Tick Borne Dis 2012; 3(4): 203-206. http://dx.doi.org/10.1016/j.ttbdis.2012.02.003. PMid:22480930.

Altschul SF, Gish W, Miller W, Myers EW, Lipman DJ. Basic local alignment search tool. J Mol Biol 1999; 215(3): 403-410. http:// dx.doi.org/10.1016/S0022-2836(05)80360-2. PMid:2231712.

Amarante AFT. Os parasitos de ovinos. São Paulo: Editora Unesp Digital; 2014. http://dx.doi.org/10.7476/97885683344423.

André MR, Duarte JMB, Gonçalves LR, Sacchi ABV, Jusi MMG, Machado RZ. New records and genetic diversity of Mycoplasma ovis in free-ranging deer in Brazil. Epidemiol Infect 2020; 148: e6. http://dx.doi.org/10.1017/S0950268819002218. PMid:31933451.

Barros-Battesti DM, Arzua M, Bechara GH. Carrapatos de Importância Médico-Veterinária da Região Neotropical: Um guia ilustrado para identificação de espécies. São Paulo: Vox/ICTTD-3/Butantan; 2006.

Birkenheuer AJ, Levy MG, Breitschwerdt EB. Development and evaluation of a seminested PCR for detection and differentiation of Babesia gibsoni (Asian genotype) and B. canis DNA in canine blood samples. J Clin Microbiol 2003; 41(9): 4172-4177. http:// dx.doi.org/10.1128/JCM.41.9.4172-4177.2003. PMid:12958243.

Brito DRB, Santos ACG, Guerra RMSNC. Ectoparasitos em rebanhos de caprinos e ovinos na microrregião do Alto Mearim e Grajau, Estado do Maranhão. Braz J Vet Parasitol 2005; 14(2): 59-63.

Dantas-Torres F, Onofrio VC, Barros-Battesti DM. The ticks (Acari: Ixodida: Argasidade, Ixodidae) of Brazil. Syst App/ Acarol 2009; 14(1): 30-46. http://dx.doi.org/10.11158/saa.14.1.4.

Darriba D, Taboada GL, Doallo R, Posada D. jModelTest 2: More models, new heuristics and parallel computing. Nat Methods 2012; 9(8): 772. http://dx.doi.org/10.1038/nmeth.2109. PMid:22847109.

Da Silva NB, Taus NS, Johnson WC, Mira A, Schnittger L, Valente JDM, et al. First report of Anaplasma marginale infection in goats, Brazil. PLoS One 2018; 13(8): e0202140. http://dx.doi.org/10.1371/journal.pone.0202140. PMid:30102734.

de la Fuente J, Atkinson MW, Naranjo V, Fernández de Mera IG, Mangold AJ, Keating KA, et al. Sequence analysis of the msp4 gene of Anaplasma ovis strains. Vet Microbio/ 2007; 119(2-4): 375-381. http://dx.doi.org/10.1016/j.vetmic.2006.09.011. PMid:17052866.

De La Fuente J, Torina A, Caracappa S, Tumino G, Furlá R, Almazán C, et al. Serologic and molecular characterization of Anaplasma species infection in farm animals and ticks from Sicily. Vet Parasitol 2005; 133(4): 357-362. http://dx.doi.org/10.1016/j. vetpar.2005.05.063. PMid:16043300.

Deshuillers PL, Santos AP, Nascimento NC, Hampel JA, Bergin IL, Dyson MC, et al. Complete genome sequence of Mycoplasma ovis strain Michigan, a hemoplasma of sheep with two distinct 16S rRNA genes. Genome Announc 2014; 2(1): e01235-e13. http:// dx.doi.org/10.1128/genomeA.01235-13. PMid:24482515. 
Di Loria A, Veneziano V, Piantedosi D, Rinaldi L, Cortese L, Mezzino L. Evaluation of the FAMACHA system for detecting the severity of anaemia in sheep from southern Italy. Vet Parasitol 2009; 161(1-2): 53-59. http://dx.doi.org/10.1016/j.vetpar.2008.12.002. PMid:19153013.

Gordon HML, Whitlock HV. A new technique for counting nematode eggs in sheep faeces. J Counc Sci Ind Res 1939; 12 : 50-52.

Grazziotin AL, Duarte JMB, Szabó MPJ, Santos AP, Guimarães AMS, Mohamed A, et al. Prevalence and molecular characterization of Mycoplasma ovis in selected free-ranging brazilian deer populations. J Wildl Dis 2011a; 47(4): 1005-1011. http://dx.doi. org/10.7589/0090-3558-47.4.1005. PMid:22102675.

Grazziotin AL, Santos AP, Guimaraes AM, Mohamed A, Cubas ZS, de Oliveira MJ, et al. Mycoplasma ovis in captive cervids: Prevalence, molecular characterization and phylogeny. Vet Microbiol 2011b; 152(3-4): 415-419. http://dx.doi.org/10.1016/j. vetmic.2011.05.001. PMid:21640523.

Hall TA. BioEdit: user-friendly biological sequence alignment editor and analysis program for Windows 95/98/NT. Nucleic Acids Symp Ser 1999; 41: 95-98.

Hassan MA, Raoofi A, Lotfollahzadeh S, Javanbakht J. Clinical and cytological characteristics and prognostic implications on sheep and goat Theileria infection in north of Iran. J Parasit Dis 2015; 39(2): 190-193. http://dx.doi.org/10.1007/s12639-013-0318-1. PMid:26063998.

Hoelzle K, Winkler M, Kramer MM, Wittenbrink MM, Dieckmann SM, Hoelzle LE. Detection of Candidatus Mycoplasma haemobos in cattle with anaemia. Vet J 2011; 187(3): 408-410. http://dx.doi.org/10.1016/j.tvjl.2010.01.016. PMid:20188610.

Hornok S, Elek V, De La Fuente J, Naranjo V, Farkas R, Majoros G, et al. First serological and molecular evidence of endemicity of Anaplasma ovis and A. marginale in Hungary. Vet Microbio/ 2007; 122(3-4): 316-322. http://dx.doi.org/10.1016/j.vetmic.2007.01.024. PMid:17336001.

Hornok S, Hajtós I, Meli ML, Farkas I, Gönczi E, Meili T, et al. First molecular identification of Mycoplasma ovis and 'Candidatus M. haemoovis' from goat, with lack of haemoplasma PCR-positivity in lice. Acta Vet Hung 2012; 60(3): 355-360. http://dx.doi. org/10.1556/avet.2012.030. PMid:22903080.

Hornok S, Meli ML, Erdos A, Hajtós I, Lutz H, Hofmann-Lehmann R. Molecular characterization of two different strains of haemotropic mycoplasmas from a sheep with fatal haemolytic anaemia and concomitant Anaplasma ovis infection. Vet Microbiol 2009; 136(3-4): 372-377. http://dx.doi.org/10.1016/j.vetmic.2008.10.031. PMid:19091491.

Instituto Brasileiro de Geografia e Estatistica - IBGE. Pesquisa da Pecuária Municipal. Efetivos de rebanho, por tipo de rebanho [online]. Rio de Janeiro: IBGE; 2016 [cited 2019 Oct 10]. Available from: https://sidra.ibge.gov.br/tabela/3939

Jalali SM, Khaki Z, Kazemi B, Bandehpour M, Rahbari S, Razi Jalali M, et al. Molecular detection and identification of Anaplasma species in sheep from Ahvaz, Iran. Majallah-i Tahqiqat-i Dampizishki-i Iran 2013; 14(1): 50-56. http://dx.doi.org/10.22099/ ijvr.2013.1389.

Kaplan RM, Burke JM, Terrill TH, Miller JE, Getz WR, Mobini S, et al. Validation of the FAMACHA ${ }^{\circ}$ eye color chart for detecting clinical anemia in sheep and goats on farms in the southern United States. Vet Parasitol 2004; 123(1-2): 105-120. http://dx.doi. org/10.1016/j.vetpar.2004.06.005. PMid:15265575.

Kessler RH. Considerações sobre a transmissão de Anaplasma marginale. Pesq Vet Bras 2001; 21(4): 177-179. http://dx.doi. org/10.1590/S0100-736X2001000400009.

Kocan KM, De La Fuente J, Blouin EF, Coetzee JF, Ewing SA. The natural history of Anaplasma marginale. Vet Parasitol 2010; 167(24): 95-107. http://dx.doi.org/10.1016/j.vetpar.2009.09.012. PMid:19811876.

Koressaar T, Remm M. Enhancements and modifications of primer design program Primer3. Bioinformatics 2007; 23(10): 12891291. http://dx.doi.org/10.1093/bioinformatics/btm091. PMid:17379693.

Lane J, Jubb T, Shephard R, Webb-Ware J, Fordyce G. MLA Final Report: Priority list of endemic diseases for the red meat industries [online] Australia: Meat and Livestock; 2015. [cited 2019 Oct 10]. Available from: https://www.mla.com.au/research-anddevelopment/search-rd-reports/final-report-details/Animal-Health-and-Biosecurity/Priority-list-of-endemic-diseases-for-thered-meat-industries/2895

Li WLS, Drummond AJ. Model averaging and Bayes factor calculation of relaxed molecular clocks in Bayesian phylogenetics. Mol Biol Evol 2012; 29(2): 751-761. http://dx.doi.org/10.1093/molbev/msr232. PMid:21940644.

Librado P, Rozas J. DnaSP v5: A software for comprehensive analysis of DNA polymorphism data. Bioinformatics 2009; 25(11): 1451-1452. http://dx.doi.org/10.1093/bioinformatics/btp187. PMid:19346325.

Ma M, Chen Z, Liu A, Ren Q, Liu J, Liu Z, et al. Biological parameters of Rhipicephalus (Boophilus) microplus (Acari: Ixodidae) fed on rabbits, sheep, and cattle. Korean J Parasito/ 2016; 54(3): 301-305. http://dx.doi.org/10.3347/kjp.2016.54.3.301. PMid:27417084. 
Machado CAL, Vidotto O, Conrado FO, Santos NJR, Valente JDM, Barbosa IC, et al. Mycoplasma ovis infection in goat farms from northeastern Brazil. Comp Immunol Microbiol Infect Dis 2017; 55: 1-5. http://dx.doi.org/10.1016/j.cimid.2017.08.004. PMid:29127988.

Marcondes M, Hirata KY, VidesJP, Sobrinho LSV, AzevedoJS, Vieira TSWJ, et al. Infection by Mycoplasma spp., feline immunodeficiency virus and feline leukemia virus in cats from an area endemic for visceral leishmaniasis. Parasit Vectors 2018; 11(1): 131. http:// dx.doi.org/10.1186/s13071-018-2716-9. PMid:29554969.

Martínez-Hernández JM, Ballados-González GG, Fernández-Bandala D, Martínez-Soto S, Velázquez-Osorio V, Martínez-Rodríguez PB, et al. Molecular detection of Mycoplasma ovis in an outbreak of hemolytic anemia in sheep from Veracruz, Mexico. Trop Anim Health Prod 2019; 51(1): 243-248. http://dx.doi.org/10.1007/s11250-018-1648-x. PMid:29934796.

Messick JB. Hemotrophic mycoplasmas (hemoplasmas): a review and new insights into pathogenic potential. Vet Clin Pathol 2004; 33(1): 2-13. http://dx.doi.org/10.1111/j.1939-165X.2004.tb00342.x. PMid:15048620.

Mongruel ACB, Ikeda P, Sousa KCM, Benevenute JL, Falbo MK, Machado RZ, et al. Molecular detection of vector borne pathogens in anemic and thrombocytopenic dogs in southern Brazil. Braz J Vet Parasito/ 2018; 27(4): 505-513. http://dx.doi.org/10.1590/ s1984-296120180069. PMid:30462822.

Morzaria TP. Theileriosis. In: Delves PJ. Encyclopedia of Immunology. 2nd ed. San Diego: Elsevier; 1998. p. 2286-2290. http://dx.doi. org/10.1006/rwei.1999.0577.

Neimark H, Hoff B, Ganter M. Mycoplasma ovis comb. nov. (formerly Eperythrozoon ovis), an epierythrocytic agent of haemolytic anemia in sheep and goat. Int Jyst Evol Microbio/ 2004; 54(Pt 2): 365-371. http://dx.doi.org/10.1099/ijs.0.02858-0. PMid:15023944.

Ozubek S, Aktas M. Molecular and parasitological survey of Ovine Piroplasmosis, Including the first report of Theileria annulata (Apicomplexa: Theileridae) in Sheep and Goats from Turkey.J Med Entomo/ 2017; 54(1): 212-220. http://dx.doi.org/10.1093/jme/ tjw134. PMid:28082649.

Rajendhran J, Gunasekaran P. Microbial phylogeny and diversity: Small subunit ribosomal RNA sequence analysis and beyond. Microbiol Res 2011; 166(2): 99-110. http://dx.doi.org/10.1016/j.micres.2010.02.003. PMid:20223646.

Rambaut A. FigtTree v1.3.1., A graphical viewer of phylogenic trees [online]. Edinburgh: Institute of Evolutionary Biology, University of Edinburgh; 2014 [cited 2019 Oct 10]. Available from: http://tree.bio.ed.ac.uk/software/figtree/

Ramos IAS, Herrera HM, Mendes NS, Fernandes SJ, Campos JBV, Alves JVA, et al. Phylogeography of msp4 genotypes of Anaplasma marginale in beef cattle from the Brazilian Pantanal. Braz J Vet Parasito/ 2019; 28(3): 451-457. http://dx.doi.org/10.1590/s198429612019049. PMid:31390434.

Renneker S, Abdo J, Salih DEA, Karagenç T, Bilgiç H, Torina A, et al. Can Anaplasma ovis in Small Ruminants be Neglected any Longer? Transbound Emerg Dis 2013; 60(Suppl 2): 105-112. http://dx.doi.org/10.1111/tbed.12149. PMid:24589109.

Ringo AE, Adjou Moumouni PF, Taioe M, Jirapattharasate C, Liu M, Wang G, et al. Molecular analysis of tick-borne protozoan and rickettsial pathogens in small ruminants from two South African provinces. Parasitol Int 2018; 67(2): 144-149. http://dx.doi. org/10.1016/j.parint.2017.11.002. PMid:29155280.

Rjeibi MR, Darghouth MA, Omri H, Souidi K, Rekik M, Gharbi M. First molecular isolation of Mycoplasma ovis from small ruminants in North Africa. Onderstepoort J Vet Res 2015; 82(1): e1-e6. http://dx.doi.org/10.4102/ojvr.v82i1.912. PMid:26244681.

Schnittger L, Yin H, Gubbels MJ, Beyer D, Niemann S, Jongejan FJ, et al. Phylogeny of sheep and goat Theileria and Babesia parasites. Parasitol Res 2003; 91(5): 398-406. http://dx.doi.org/10.1007/s00436-003-0979-2. PMid:14505044.

Sela I, Ashkenazy H, Katoh K, Pupko T. GUIDANCE2: accurate detection of unreliable alignment regions accounting for the uncertainty of multiple parameters. Nucleic Acids Res 2015; 43(W1): W7-W14. http://dx.doi.org/10.1093/nar/gkv318. PMid:25883146.

Sevinc F, Zhou M, Cao S, Ceylan O, Aydin MF, Sevinc M, et al. Haemoparasitic agents associated with ovine babesiosis: A possible negative interaction between Babesia ovis and Theileria ovis. Vet Parasitol 2018; 252: 143-147. http://dx.doi.org/10.1016/j. vetpar.2018.02.013. PMid:29559137.

Souza UA, Oberrather K, Fagundes-Moreira R, Almeida BA, Valle SF, Girotto-Soares A, et al. First molecular detection of Mycoplasma ovis (Hemotropic mycoplasmas) from Sheep in Brazil. Braz J Vet Parasitol 2019; 28(3): 360-366. http://dx.doi.org/10.1590/s198429612019022. PMid:31215606.

Taylor MA, Coop RL, Wall RL. Veterinary parasitology. 3th ed. Ames, lowa: Wiley-Blackwell; 2007.

Tian Z, Liu G, Yin H, Xie J, Wang S, Yuan X, et al. First report on the occurrence of Theileria sp. OT3 in China. Parasitol Int 2004; 63(1): 403-407. http://dx.doi.org/10.1016/j.parint.2013.12.014. PMid:24388914.

Ueno H, Gonçalves PC. Manual para Diagnóstico das Helmintoses de Ruminantes. 4 ed. Tóquio: Japan International Cooperation Agency; 1998.

Uilenberg G. Babesia - A historical review. Vet Parasitol 2006; 138(1-2): 3-10. http://dx.doi.org/10.1016/j.vetpar.2006.01.035. PMid:16513280. 
Untergasser A, Cutcutache I, Koressaar T, Ye J, Faircloth BC, Remm M, et al. Primer3 - New capabilities and interfaces. Nucleic Acids Res 2012; 40(15): e115. http://dx.doi.org/10.1093/nar/gks596. PMid:22730293.

Wang X, Cui Y, Zhang Y, Shi K, Yan Y, Jian F, et al. Molecular characterization of hemotropic mycoplasmas (Mycoplasma ovis and 'Candidatus Mycoplasma haemovis') in sheep and goats in China. BMC Vet Res 2017; 13(1): 142. http://dx.doi.org/10.1186/s12917017-1062-z. PMid:28549435.

Weiss DJ, Wardrop KJ, Schalm OW. Schalm's Veterinary Hematology. 4th ed. Ames, lowa: Wiley-Blackwell; 2010.

Willi B, Boretti FS, Tasker S, Meli ML, Wengi N, Reusch CE, et al. From Haemobartonella to hemoplasma: molecular methods provide new insights. Vet Microbio/ 2007; 125(3-4): 197-209. http://dx.doi.org/10.1016/j.vetmic.2007.06.027. PMid:17706380.

Yang J, Han R, Niu Q, Liu Z, Guan G, Liu G, et al. Occurrence of four Anaplasma species with veterinary and public health significance in sheep, northwestern China. Ticks Tick Borne Dis 2018; 9(1): 82-85. http://dx.doi.org/10.1016/j.ttbdis.2017.10.005. PMid:29037826.

Yang J, Li Y, Liu Z, Liu J, Niu Q, Ren Q, et al. Molecular detection and characterization of Anaplasma spp. in sheep and cattle from Xinjiang, northwest China. Parasit Vectors 2015; 8(1): 108. http://dx.doi.org/10.1186/s13071-015-0727-3. PMid:25889906.

Yeruham I, Hadani A, Galker F. Some epizootilogical and clinical aspects of ovine babesiosis caused by Babesia ovis - a Review. Vet Parasitol 1998; 74(2-4): 153-163. http://dx.doi.org/10.1016/S0304-4017(97)00143-X. PMid:9561703.

Yousefi A, Rahbari S, Shayan P, Sadeghi-dehkordi Z, Bahonar A. Molecular detection of Anaplasma marginale and Anaplasma ovis in sheep and goat in west highland pasture of Iran. Asian Pac J Trop Biomed 2017; 7(5): 455-459. http://dx.doi.org/10.1016/j. apjtb.2017.01.017.

Zhang Y, Lv Y, Zhang F, Zhang W, Wang J, Cui Y, et al. Molecular and phylogenetic analysis of Anaplasma spp. in sheep and goats from six provinces of China. J Vet Sci 2016; 17(4): 523-529. http://dx.doi.org/10.4142/jvs.2016.17.4.523. PMid:27456776. 